\title{
THE ROLE OF MANAGEMENT ACCOUNTING PRACTICES IN DETERMINING CUSTOMER SATISFACTION:
}

\section{THE CASE OF SRILANKAN FIRMS}

BW

PANCHERIINIE Gr. DIAS

Thesis submitted to the University of Sri Jayawardenepura for the award for the Degree of Master of Science in Management on July 2011 


\section{DECLARATION}

I certify that the above statement made by the candidate is true and that this thesis is suitable for submission to the University for the purpose of evaluation.

$$
29-11-2012
$$

Date

Name of the Supervisor: Prof. T.M.B.Palawatta
TmBPalawdts

Signature of the Supervisor:

Approved by the Examining Committee

M.Sc. (Management) Program

Senifor PSS H. H.D.N.P Opathe

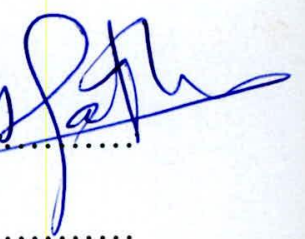




\section{TABLE OF CONTENTS}

Table of contents

List of Tables

iii

List of Figures

List of Abbreviations vii

Acknowledgement viii

Abstract $\quad$ ix

Chapter 1: Introduction 1

1.1 Research Problem 4

1.2 Research Objectives 4

$\begin{array}{ll}\text { Chapter 2: Literature Review } & 10\end{array}$

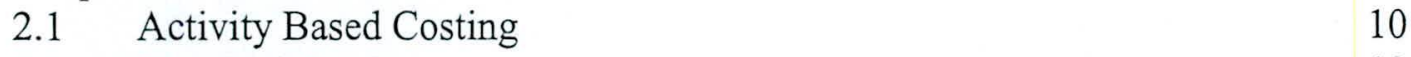

$\begin{array}{lll}2.2 & \text { Standard Costing } & 13\end{array}$

$\begin{array}{ll}2.3 \text { Life Cycle costing } & 16\end{array}$

$\begin{array}{lll}2.4 & \text { Target Costing } & 16\end{array}$

$\begin{array}{ll}2.5 & \text { Quality Costing } \\ 2.6 & 18\end{array}$

$\begin{array}{ll}2.6 & 19 \\ 2.7 & \text { Budgeting }\end{array}$

2.7 Customer Profitability Analysis 23

2.8 Cost Volume Profit Analysis 26

$\begin{array}{ll}2.9 \text { Benchmarking } & 27\end{array}$

2.10 Customer Relationship Management 28

$\begin{array}{ll}2.11 \text { Total Quality Management } & 30\end{array}$

2.12 Performance Measurement 32

2.13 Balanced Score Card 33

\begin{tabular}{ll}
2.14 & Value Chain Analysis \\
\hline
\end{tabular}

$\begin{array}{lll}2.15 & \text { SWOT Analysis } & 37\end{array}$

2.16 Customer Satisfaction 38

Chapter 3: Conceptual Framework and Hypothesis 39

$\begin{array}{lll}3.1 \text { Introduction } & 39\end{array}$

3.2 Development of the Models and Hypothesis 39

Chapter 4: Research Methodology 45

4.1 Introduction 45

4.2 Operationalization of Variables 45

4.3 Data Collection Process 56

4.4 Sample Size and Justification $\quad 57$ 
Chapter 5: Data Presentation and Analysis

$\begin{array}{lll}5.1 & \text { Introduction } & 58\end{array}$

5.2 Reliability of the Data Set 58

$\begin{array}{ll}5.3 \text { Presentation of Variables } & 59\end{array}$

$\begin{array}{lll}5.4 & \text { Descriptive Statistics } & 123\end{array}$

5.5 Effect of Management Accounting Practices on Overall Satisfaction 129

$\begin{array}{lll}5.6 & 139\end{array}$

$\begin{array}{ll}5.7 & \text { Development of Overall model } \\ & 142\end{array}$

Chapter 6: Discussion on Findings $\quad 152$

$\begin{array}{lll}6.1 \text { Introduction } & 152\end{array}$

6.2 Findings 152

$\begin{array}{lll}6.3 & \text { Overall Model } & 156\end{array}$

$\begin{array}{ll}\text { 6.4 Managerial Implications } & 157\end{array}$

Chapter 7: Implication for future research and conclusions $\quad 161$

$\begin{array}{lll}7.1 & \text { Introduction } & 161\end{array}$

$\begin{array}{ll}7.2 & \text { Implications for further Research } \\ 761\end{array}$

$\begin{array}{lll}7.3 & \text { Limitations } & 164\end{array}$

$\begin{array}{lll}7.4 & \text { Conclusion } & 164\end{array}$

$\begin{array}{ll}\text { References } & 165\end{array}$

Appendices

$\begin{array}{ll}\text { Appendix I Questionnaire Finance Department } & 174\end{array}$

Appendix II Questionnaire HR Department 182

Appendix III Questionnaire Marketing Department 183

$\begin{array}{ll}\text { Appendix IV Questionnaire OM Department } & 187\end{array}$

$\begin{array}{ll}\text { Appendix V Questionnaire Customer Satisfaction } & 188\end{array}$ 


\section{LIST OF TABLES}

1. Table 1 : Classification of Management Accounting Tools

2. Table 2 : Reliability Statistics

3. Table 3: Descriptive Statistics

4. Table 4: Descriptive Statistics

5. Table 5: Descriptive Statistics

6. Table 6: Descriptive Statistics

7. Table 7: Descriptive Statistics

8. Table 8: Descriptive Statistics

9. Table 9: Regression Coefficients: Dependent Variable Overall Satisfaction

10. Table10: Model Summary- Predictors -Management Accounting Practices

11. Table11: ANOVA -Predictors-Management Accounting Practices

12. Table 12: Coefficients- Predictor- Management Accounting Practices

13. Table 13: Model Summary- Predictors - Significant Management Accounting Practices

14. Table 14: ANOVA -Predictors -Significant Management Accounting Practices

15. Table 15: Coefficients- Predictor- Significant Management Accounting Practices

16. Table 16: Model Summary- Satisfaction Model

17. Table 17: ANOVA-Satisfaction Model

18. Table18: Coefficients -Satisfaction Model

19. Table19: Model Summary- Significant Satisfaction Model

20. Table20: ANOVA-Significant Satisfaction Model

21. Table21: Coefficients-Significant Satisfaction Model

22. Table22: Correlations - Significant Satisfaction Predictor Variables

23. Table23: Model Summary- Overall Model

24. Table24: ANOVA-Overall Model

25. Table25: Coefficients- Overall Model

26. Table26: Model Summary- Second Overall Model

27. Table27: ANOVA-Second Overall Model

28. Table28: Coefficients- Second Overall Model

29. Table29: Model Summary- Final Overall Model

30. Table30: ANOVA-Final Overall Model

31. Table31: Coefficients- Final Overall Model 


\section{LIST OF FIGURES}

1. Figure 3.1- Conceptual Model 1

2. Figure 3.2 Conceptual Model -Satisfaction Model .

3. Figure 5.1 Histogram- Principle activities / products of the company- Type of Business

4. Figure 5.2 Histogram -Place of Registration

5. Figure 5.3Histogram - Whether listed on the stock exchange

6. Figure 5.4 Histogram-Whether the organization has a separate management accounting unit

7. Figure 5.5 Histogram-Total number of employees

8. Figure 5.6 Histogram-Value of turnover

9. Figure 5.7 Histogram-Budgets

10. Figure 5.8 Histogram -Standard Costing \& Variance analysis

11. Figure 5.9 Histogram-Cost volume profit analysis

12. Figure 5.10 Histogram- Performance measurement

13. Figure 5.11Histogram-Target costing

14. Figure 5.12Histogram - ABC (Activity Based Costing)

15. Figure5.13Histogram-BCS ( Balance score card costing

16. Figure5.14Histogram-Life cycle costing

17. Figure5.15Histogram-Quality costing

18. Figure5.16Histogram-Value Chain costing

19. Figure5.17Histogram-Benchmarking

20. Figure5.18Histogram-Customer profitability analysis

21. Figure5.19Histogram - Total quality management

22. Figure5.20Histogram-Customer relationship management

23. Figure5.21Histogram-SWOT Analysis

24. Figure5.22 Histogram-Cost Design

25. Figure 5.23 Histogram-Cost planning

26. Figure5.24 Histogram-Cost control

27. Figure5.25 Histogram-Product pricing

28. Figure5.26 Histogram-Decision making

29. Figure5.27 Histogram-Strategic management

30. Figure 5.28 Histogram-Performance evaluation

31. Figure5.29 Histogram-Budgetary control

32. Figure 5.30 Histogram- Value creation

33. Figure 5.31 Histogram- Follow Competitor

34. Figure 5.32 Histogram-Save time 
35. Figure 5.33 Histogram -Save cost

36. Figure 5.34 Histogram -Easy to use

37. Figure 5.35 Histogram -Increase production

38. Figure 5.36 Histogram -Required by customer

39. Figure 5.37 Histogram -Computer aided design

40. Figure 5.38 Histogram -Computer aided engineering

41. Figure 5.39 Histogram -Computer aided manufacturing

42. Figure 5.40 Histogram -Robotics

43. Figure 5.41 Histogram -Flexible manufacturing systems

44. Figure 5.42 Histogram -Computer aided inspection \& testing

45. Figure 5.43 Histogram -Computer usage in purchasing production / scheduling

46. Figure 5.44 Histogram -Automatic physical data collection

47. Figure 5.45 Histogram -Numeric control machine

48. Figure 5.46 Histogram -Automation of transport \& storage

49. Figure 5.47 Histogram -Electronic correspondence with suppliers \& buyers

50. Figure 5.48 Histogram-Online system

51. Figure 5.49 Histogram- Follow Competitor

52. Figure 5.50 Histogram- Save time

53. Figure 5.51 Histogram -Save cost

54. Figure 5.52 Histogram -Easy to use

55. Figure 5.53 Histogram -Increase production

56. Figure 5.54 Histogram -Required by customer

57. Figure 5.55 Histogram- Whether current practices need improvement

58. Figure 5.56 Histogram- How long they were used without any changes

59. Figure 5.57 Histogram -Number of employees in the department

60. Figure 5.58 Histogram -Average age of the employees in the department

61. Figure 5.59 Histogram- Key marketing objectives

62. Figure 5.60 Histogram -Are the information given by finance department relevant to marketing

63. Figure 5.61 Histogram -Whether marketing department find finance department responding to customer needs

64. Figure 5.62 Histogram -Degree of satisfaction of the marketing department with the services provided by the finance

65. Figure 5.63 Histogram- Number of HR employees

66. Figure 5.64 Histogram -Average age of HR employees

67. Figure 5.65 Histogram- Key Functions of HR department

68. Figure 5.66 Histogram -Relevance of Finance MIS to HR

69. Figure 5.67 Histogram -Finance Adhering to HR Practices

70. Figure 5.68 Histogram -Satisfaction of HR with the services of Finance

71. Figure 5.69 Histogram -Number of OM employees.

72. Figure 5.70 Histogram -Average age of OM employees

73. Figure 5.71 Histogram - The Variable relevance of finance to MIS to OM 
74. Figure 5.72 Histogram- The variable Finance adhering to OM

75. Figure 5.73 Histogram -The variable OM satisfaction with the finance

76. Figure 5.74 Histogram - Average purchases from the company

77. Figure 5.75 Histogram -How many customer complaints have been made

78. Figure 5.76 Histogram -Customer service with regard to issue resolution

79. Figure 5.77 Histogram -Customer service with regard to quality of advice

80. Figure 5.78 Histogram- Customer service with regard to promptness of answering phone

81. Figure 5.79 Histogram -Customer service with regard to overall quality of issue handling

82. Figure 5.80 Histogram -Professionalism of representatives

83. Figure 5.81 Histogram -Helpfulness of representatives

84. Figure 5.82 Histogram -Ease of contacting customer service

85. Figure 5.83 Histogram -Promptness of email responses

86. Figure 5.84 Histogram-Accuracy of the service

87. Figure 5.86 Histogram -Degree of dependability

88. Figure 5.87 Histogram -Degree of comfortableness

89. Figure 5.88 Histogram -Degree of pleasantness

90. Figure 5.89 Histogram -Degree of cleanliness

91. Figure 5.90 Histogram -Degree of convenience

92. Figure 5.91 Histogram- Satisfaction level with the product/ services of the Company

93. Figure 5.92 Histogram -Satisfaction level with the Company overall.

94. Figure 5.93 Significant Management Accounting practices model

95. Figure 5.94 Significant Satisfaction Model

96. Figure 6.1 Significant Management Accounting Practices Model

97. Figure 6.2 Significant Satisfaction Model

98. Figure 6.3 Significant Overall Model

99. Figure 6.4 Satisfaction model

100. Figure 6.5 Overall Model

101. Figure 7.1 Significant Satisfaction Model

102. Figure 7.2 Significant Overall Model 


\section{LIST OF ABBREVIATIONS}

1. $\mathrm{ABC}$ Activity Based Costing

2. SC Standard Costing

3. LCC Life Cycle Costing

4. TC Target Costing

5. QC Quality Costing

6. $\mathrm{BG}$ Budgeting

7. CPA Customer Profitability Analysis

8. CVPA Cost Volume Profit Analysis

9. BM Benchmarking

10. CRM Customer Relationship Management

11. TQM Total Quality Management

12. PM Performance Management

13. BSC Balanced Score Card

14. VCA Value Chain Analysis

15. SWOTA SWOT Analysis 


\section{ACKNOWLEDGEMENTS}

At the outset, I wish to express my humble and sincere gratitude to my Supervisor Prof T.M.B. Palawatta, University of Sri Jayawardhanapura for his supervision, guidance and valuable comments which was vital \& instrumental to complete this study.

I wish to thank all respondents who extended their cooperation, and all others who helped me in numerous ways, and regret my inability to mention their names here individually. While appreciating efforts of the past researchers, I wish to thank them as their studies were of great help to set about my research, though some of the points of view have been subjected to constructive criticism in this Thesis.

I thank Ms. Nillupuli Gunawardena, Ms. Pamela Ratnam and Ms. Rozanne Moraes for assisting me in data collection. I wish to extend my heartfelt gratitude to all the financial heads of Senok group of companies and the Chartered Institute of Management Accountants UK (Sri Lanka Division) for obtaining permission from the relevant organizations for the data collection.

Finally, I acknowledge with gratitude the corporation \& understanding of my husband Nishantha Dias and daughters Chrishella \& Roshella that made the conduct of this research possible amidst my heavy official commitments. 


\title{
The role of Management Accounting Practices in Determining \\ Customer Satisfaction: The Case of Sri Lankans Firms
}

\author{
Pancherine G. Dias
}

\begin{abstract}
This research examines the role of management accounting practices in determining customer satisfaction. All together 15 management Accounting practices were used in the study. Namely, Activity Based Costing, Standard Costing, Life Cycle Costing, Target Costing, Quality Costing, Budgeting, Customer Profitability Analysis, Cost Volume Profit Analysis, Benchmarking, Customer Relationship Management, Total Quality Management, Performance Management, Balanced Score Card, Value Chain Analysis, SWOT Analysis are the practices that were considered in the study .

Of the fifteen management accounting practices included in the study only seven of them, particularly, Budgets, Standard Costing \& Variance analysis , Cost volume profit analysis, Customer profitability analysis, Total quality management, Customer relationship management, SWOT Analysis have significant relationships.

Of the significant relationships Budgeting, Customer Profitability Analysis, Total Quality Management and Customer Relationship Management have negative relationships. Standard Costing, Cost Volume Profit Analysis and SWOT Analysis have positive relationships.
\end{abstract}

Second model tested in the study was the satisfaction model. It was found that OM Satisfaction with Finance and Product/Service Satisfaction have positive effects on the Overall Satisfaction with the company. Surprisingly, HR Satisfaction with Finance and 
Marketing Satisfaction with Finance did not have significant effects on overall satisfaction

Third, attempt was made to develop an overall model. It was found that Product /Service Satisfaction, Degree of Pleasantness, Do Marketing Find Finance Responding to Customer Needs and Do You Find Finance Adhering to HR practices are found to be important in determining overall customer satisfaction. All three models developed in the study are new to the field of education in management research. 


\section{CHAPTER 1: INTRODUCTION}

There are several studies conducted on management accounting practices (A Keivan Zokaei and David W. Simons(2006) ;Value chain analysis in consumer focus improvement ,Alaa M. Ghalayini and James S. Noble(1996); The changing Basis of performance measurement, Andrea Plezeter(2007 );Building optimization with life cycle costs - the influence of calculation methods, Andrea Schiffauerova and Vince Thomson (2005); A review of research on COQ models, Andrew Booht(2006); Counting what counts, performance measurement and evidence based practice, Performance Measurement and metrics, Andrew Goddard(2004); Budgetary practices and Accountability habits: A grounded theory, Andy Neely, Mike Bourne and Chris Adams(2003);Better budgeting or beyond budgeting?, Azizi Jafar, Taleghani Mohammad, Esmaielpoor Fariba and Gudarzvand Chegini Mehrdad(2010); Effect of the Quality Costing System on Implementation and Execution of Optimum Total Quality Management, Gopalakrishnan, A. Kokatnur and D. P. Gupta(2007) ;Design and development of target costing system for turning operation, Basu, Onker N, Conrad, Edward J,(1994); Cost - Volume - Profit Analysis, Beverley R Lord, Yvonne P. Shanahan and Michelle J. Gage(2005); The Balanced Scorecard, Charls Parker(2000) Performance Measurement Work Study, Christopher Musico, Chordiant(2000) Focuses on improving customer lifetime value, David H. Taylor(2005); Value chain analysis: an approach to supply chain improvements in agri-food chains, Denis Leonard and Rodney McAdam(2002); The strategic impact and implementation of TQM, Dilanthi Amarathunga, David Baldry and Marjan Sarshar(2001);Process improvement through performance 
measurement: the balanced scorecard methodology, Douglas M. Lambert(2009); customer relationship management as business process, H. James Harrington(1999); Performance Improvement: a total poor-quality cost system, J. Scot Armstrong(2004); Don't do SWOT: A note on marketing planning, Jan Achterbergh, Robert Beeres, and Dirk Vriens(2003); Does the Balanced Scorecard support organizational viability? Jianxin Jiao and Mitchell M. Tseng (1999);A pragmatic approach to product costing based on standard time estimation, John C. Lere(2000) Activity - based costing: a powerful tool for pricing, John Hallaway(1982); A Money sever: Life cycle costing, Lisa Mc Manus(2007); Construction of a Segmental customer profitability analysis, Lucas, Mike (1999); Standard costing and its role in today's manufacturing environment, Mahmoud M. Yasin (2002); The theory and practice of benchmarking: then and now,Maliah Sulaiman, Nik Nazli Nik Ahmad and Norhayati Mohd Alwi (2005); Is standard costing obsolete?, Manoochehr Najmi, John Rigas and Ip-Shing Fan(2005) A framework to review performance measurement systems, Margaret L. Gagne and Richard Discenza(1995); Target Costing,Marie, Attiea, Rao, Ananth,(2010);“Is standard costing still relevant? Evidence from Dubai”, Marilyn M. Helms, Lawrence P. Ettkin, Joe t. Baxter, Matthew W. Gordon(2005); Managerial Implications of Target Costing, Milorad M. Novicevic and Michael Harvey(2004); Dualperspective SWOT: a synthesis of marketing intelligence and planning. Fernandez I.P. McCarthy and T. Rakotobe-Joel(2001);An evolutionary approach to benchmarking, Patricia Everaert, Stijn Loosveld, Tom Van Acker, Marjike Schollier and Gerrit Sarens(2006); Characteristics of target costing: theoretical and field study perspectives, Paul A. Phillips, Welsh Hotel(1994);Cost-Volume-Profit Analysis and uncertainty, Paul Hepworth, Weighing it up (1998) a literature review for the balances scorecard, Paul Quek Eng \& 
Shari Mohomad Yusof(2003);A Survey of TQM practices in the Malaysian electrical and electronic industry, Rune M. Moen(1998) New quality cost model used as a top management tool,Sandra Cohen, George Venieris and Efrosini Kaimenakai (2005);ABC: adopters, supporters, deniers, and unaware, Sue Llewellyn(1998);Publishing budgets down the line: ascribing financial responsibility in the UK social Services, Tajinder Pal Singh Toor(2009); Creating competitive edge through improved customer relationship management, Ulrika Hellsten and Bengt Klefsjo (2000);TQM as a management system consisting of values, techniques and tools.

Similarly there are also many studies conducted on the dependent variable customer satisfaction . Namely Anderson,Rolp E( 1973; “Consumer Dissatisfaction : The effect of Disconfirmed Expectancy on Percieved Product Performance,"Cronin ,J.J., and S.A.Taylor ( 1992 ); “ Measuring Service Quality : A Reexamination and Extensions ,"Cronin ,J.J., and S.A.Taylor ( 1994 ); " SERVPERF vs SERVQUAL ," Davis ,M.M and Heinneke , J ( 1994), " How disconfirmation, perception and actual times impact customer satisfaction ", Parasuraman ,A., Valerie A.Zeithaml and Leonard Berry (1994 ) ; "Reassessment of expectation as a comparison standard on measuring service quality: Implications for future research “, Teas ,R.Kenneth ( 1993 ); “ Expectations, performance evaluation and consumers' perception of quality," are some of the pioneering studies on the variable customer satisfaction .

However, the relationship between management accounting \& customer satisfaction is a topic which is barely researched. Therefore the research problem and the objectives of the study are organized as follows. 